\title{
The Miniaturization of the World in Moacyr Scliar's A Guerra no Bom Fim
}

Lyslei Nascimento

DOI - 10.25160/v5i2.ga.5

The miniature is one of the dwelling places of grandeur. Bachelard

God is in the details. So is the Devil. Umberto Eco

In the "The Rigor of Science," Jorge Luis Borges provides a map and monstrous mapmakers:

...In that Empire, the Art of Cartography reached such perfection that the map of a single Province occupied the entire City, and the map of the Empire, an entire Province. In time, these colossal Maps were not satisfactory and the Colleges of Cartographers devised a Map of the Empire that was the size of the Empire and coincided precisely with it. Less accustomed to the Study of Cartography, the Following Generations understood that this dilated Map was useless and not without impiousness delivered it over to the severities of the Sun and Winter. In the deserts of the West, ruins of the Map hung in shreds, inhabited by Animals and Beggars. In the whole Country there is no other relic of the Geographical Disciplines. (Suárez Miranda: Travels of Prudent Gentleman, fourth book, chapter XLV, Lérida, 1658). (Borges, 2000:247)

Monstrosity, present in the undertaking of this "college of map-makers," can be glimpsed in the desire for absolute coincidence between map and empire. Such arrogance makes the art of the map-maker (which, as art, might have had imagination and fantasy) demoted to one of the geographical disciplines.

Moacyr Sciliar's novel A guerra no Bom Fim, originally published in 1972, on the contrary, establishes a counterpoint to this enterprise of Borges' geographers. The narrative portrays the Second World War and its devastating effects on Bom Fim, the Jewish neighborhood of the city of Porto Alegre. From a child's point-of-view, this space 
for fantasy and dream but also of nightmares and bad omens is shaped like "a small country," which reveals in its shape the world miniaturized and brutalized by the war.

This space inhabited by the imagination of the children with animals and monstrous hybrid beings composes a Chagall-like scene that permits us to discern the literary and artistic intertexts dear to Scliar's fiction. This reduced space of the Jewish neighborhood, of the representation of the war, and of the strange beings that inhabit it beyond an immense map of reality, produces a fiction in which the miniature points to a kind of poetics, a form of literary construction by the author, the construction of a world miniaturized by the activating fiction of unforeseen similarities and sublimities. In the miniature, as Gaston Bachelard claims, "are the condensed and enriched," and "one needs to go beyond logic to experience what there is of greatness in smallness."

Literary miniatures often appear in Scliar's work. In "The She-Bears," for example, by appropriating the Biblical episode in which the Prophet Elisha, when he is called "baldy" by some boys, curses them in the name of the Lord, the miniaturized space activates the curse. Two large she-bears then emerge from the woods and devour fortytwo boys. From then on, however, the reader perceives a deviation in the form of an interpellation. Some of the boys who are eaten are not reduced to particles and attacked by powerful acids, but fall into the enormous stomach of the bear. There they stay, and, in the end, adapt:

They grew, but not very much. The confined space did not allow it. They became a curious race of dwarves, with short members and large heads where eyes like beacons always shone to examine the darkness of the entrails. And there they made their little city, with cute little houses painted white. The little schoolhouse. The little town hall, the little hospital. And they were happy. (Scliar, 2003b: 226)

After the foundation of this minimal town, there follows in the narrative a series of diminished parts: tiny barns, factories, foods, things, cinemas, churches, clubs, roads. The enumeration of the tiny things forms an agonic space and after years of happiness the conflict between generations ends up by causing the children to be born "with long arms and legs, well-proportioned heads, and soft brown eyes."(Slciar, 2003b: 225)

The first generation of dwarves, monstrous from the deformations inherent in the space and harsh conditions of life in the stomach of a bear, is superimposed on another, 
stronger, and apparently less strange generation. The little town also has its rigid, bald prophet who has an intimidating look. The government thinks of consulting him on the appropriateness of executing babies as soon as they are born. Time goes by, the children grow up, and nothing can contain them. They invade the tiny cinemas, churches, and clubs. They respect no one, not even the police. One day, the narrator relates, the prophet is walking up the street to his little mansion when the boys spot him and mock him, calling him "baldy." The prophet turns and, as in the former case, curses them. Shortly afterward, two she-bears appear and devour the boys, closing the narrative cycle, but opening it up infinitely to the struggle between parents and children, or, ratifying the generational conflict by making evident how youth stops being a promise to become a threat.

In the story "The Dwarf in the Television Set," the construction of space is distressing from the beginning, not only because of the reduced space, but because this space is inhabited by a person. The reader accompanies the story and the impressions, in the first person, of the dwarf who observes the life of Gaston, the owner of a television shop. He makes observations like this: "Being a dwarf and living inside a television set even if it is a gigantic, color set - is terrible [...]." (Scliar, 2003b: 380) If, in the former story, the enumeration of nouns is notable, in this one, the diminishment of life inside the television set is contrasted with the immense size of the apartment. More than this unusual space inhabited by the dwarf, the circumstance of being boxed in means speculating on Gaston's condition. From his metaphorical closet, he harasses an employee; the television screen from which the dwarf observes Gaston therefore becomes a mirror of Gaston's life in the closet.

The first paragraph of the novel Cenas da vida minúscula [Scenes from lower-case life] sets the tone of the narrative: "What I know today is not little; therefore, I begin with Kafka, who sums up everything in this aphorism: "Two possibilities: to be infinitely small or make oneself infinitely small. The first possibility is perfection, therefore inaction; the second is the beginning, therefore action." (Scliar, 2003: 5) The narrator of the story is a descendent of King Solomon, who, in the city of São Paulo, remembers his appearance in the world by means of magic formulae, cabalas, and other alchemies. Born about ten centimeters tall in the Amazon forest, this strange narrator with a prodigious memory joins, not without irony, a tradition of Lilliputians, such as Tom Thumb and the homunculi and miniscule beings of Paracelsus. All these references begin with the roundthe-world journey of the narrator's ancestors, who from the reign of Solomon to the Amazon forest, note their adventures down in a magical book that rivals the Book. The rivalry with Adam, which is glimpsed in the narrative, also occurs, mirroring the holy 
book that, in the novel, is written by Sulamite, one of Solomon's daughters. The game of mirrors with the Biblical narrative duplicates the name of the muse of the Song of Songs and imposes on it the task of writing the history of the Jewish people. Her insurrection, however, is inspired by Lilith:

I do not submit. I prophesy the thoughts of Yahweh: "The Lord said to Himself," I write, in a certain passage. Dost thou understand, Habakkuk? "The Lord said to Himself." God is omniscient, but I am more omniscient than God, I know what he thinks. He will not defeat me, Habakkuk, not even $\mathrm{He}$, or his agent Solomon. He created heaven and earth, but I create the text in which he dwells. (Scliar, 2003: 21)

Writing, this desire to create a text that God inhabits, is shaped like a feminine story, seen from below: that of the complex relation between women and the sacred. If the ancestors of the little narrator, generation after generation, continue copying the divine act of the Creation of man, the young copyist, in his small insurrection, throws suspicion on the construction of the sacred and its mystifications when the question is writing and its relations with power.

In A Guerra no Bom Fim, the miniaturized world is the neighborhood of Bom Fim in Porto Alegre, inhabited by children who, in a lyrical childhood, intertwine war and violence with the life in the little country of Bom Fim. Childhood rules the story, and the miniature of the children's games is proposed to encompass an imaginary value, which is fantasy. "Let us consider Bom Fim a country - a small country, not a neighborhood of Porto Alegre." In this way the narrator initiates the reader into this tiny world that owes nothing to geography or real history with its maps and manuals:

It is bounded, on the North, by the columns of the Windmills; on the West, by the town center; on the east, by the African Colony, and, farther on, Petropolis and the Three Fig-Trees; on the south, by the Várzea plain, from which it is separated by Avenida Oswaldo Aranha. In 1943, the Várzea region, by then made habitable, was transformed into a park Redenção [Redemption] - in the center of which the police had set up a little fort; outside this island of safety the nights of Redenção were dangerous, especially in the winter, when the fog invaded those low 
lands. A veritable sea, where feeble spots of light floated here and there. (Scliar, 2004: 5)

The imaginary limits of the neighborhood are described, therefore, without any commitment to the real city. In this sense, "littleness is not ridiculous, but marvelous."(Bachelard, 1993: 172) As a kind of counterpoint to the vast map of the Borgean geographers, in the space created by Scliar in this Bom Fim of childhood, all the borders are diluted, new and unusual margins also produce unusual cultural interchanges, like the friendship between the boys Joel and Nathan and the black man whose nickname was Macumba. If, as Bachelard would have it, metaphorically, the minuscule is the dwelling-place of greatness, the appearance of Macumba transforms the Jewish family:

The large black Macumba rose from the back of Joel's house after the heavy rains that preceded the Passover feast. The backyard was transformed into a veritable sea, a great sea of muddy water... He was standing still. He was huge and he had a saw in his hand. He looked to Shendl just as threatening as the Pharaoh was to the Jews in Egypt. (Scliar, 2004: 30)

Following this appearance, which will interweave the Biblical story of the Exodus with Joel's family, is a terrifying vision. In the narrator's eyes, Macumba, insensitive to imaginary floggings, plagues, locusts and frogs, ulcers, blood and wounds, walks toward the frightened woman, who had a knife in her hand. Indifferent to this threat, which reverses the Biblical story, Macumba responds with a gentle greeting, asking if there was any wood to be cut and, through this work he earns a piece of bread.

A friend of the children, Macumba was, therefore, "an enemy of the Nazis and a friend of King Joel, for whom he becomes as wise as Solomon for the teaching of valuable secrets." (Id. Ibid) According to the narrator, thanks to a dispatch sent by Macumba the group won the Battle of Guadalcanal, at the corner of Vasco da Gama and Fernandes Vieira. The territory of the war thus migrates to Bom Fim and the first land victory of the Allies in the Second World War, fought from August 1942 to February 1943 between Americans and Australians against the Japanese in the Pacific, the turning-point of the war, was owed, with graceful humor, to a dispatch of the black man Macumba. 
In addition, the enumeration of a human fauna that lives in the Jewish neighborhood also reveals the physical and moral degradation of the place:

During the Day one saw the extinct volcano. The petrified tree. The Chinese House. Cypresses over the lake. Boats. An alligator well. Ruins of ancient civilizations, among them, half hidden, unruly pederasts. The cranes and the capybaras. Buffalo. A harpy. The lake of voracious carp. And on Sundays, soldiers in yellow uniforms, housemaids with parasols, popcorn-vendors. Beside the boat house, the Salvation Army band played, having inscribed on their banner's pole: IRON AND FIRE. (Scliar, 2004: 6)

This list, which includes an extinct volcano, a petrified tree, a Chinese house, cypresses, boats, well, and lake, form this unusual space of the narrative. As in Borges' text, it points to "ruins of ancient civilizations," not to the total representation of its geography. A strange bestiary that does not exempt the human from being mixed up with this enumeration: pederasts, alligators, cranes, capybaras, buffalo, a harpy, and voracious carp, as well as soldiers, housemaids, street-vendors, and musicians of a religious band.

We might add to this bestiary Joel's brother, the frail Nathan, who looks like the violinists on the roof of Sholem Aleichem and Marc Chagall. As is known, Teyve, the Milkman will be the origin of Norman Jewison's musical The Violinist on the Roof, of 1964, but it is in the work of Chagall that the violinist achieves his most provocative representation.

Marc Chagall was born in 1887, in Vitebsk, now Belorussia. From a traditional family, the artist lived through the period of pre-revolutionary Russia, especially difficult for Jews owing to the persecutions of the Czarist regime. He also suffered from antiSemitism when his works were considered "degenerate Jewish art" and destroyed in Nazi Germany. The dream world of colorful cows and goats and courting couples that floated in the air came to inhabit, intertextually, Scliar's novel.

When the author constructs the Bom Fim neighborhood, many of the villages painted by Chagall are evoked therein. Despite being cosmopolites, Chagall and Scliar were anchored in the simple life of the small Jewish city, the schtlel. As Bachelard writes: "Values are engulfed in the miniature" and "the miniature makes one dream." (Bachelard, 
1993: 160) Thus, the little violinists that illuminate the little cold and ashen cities of Europe come, in Scliar's writing, to give Nathan wings. According to the story:

Although surrounded by hills, Bom Fim is a flat country. To see Macumba, Nathan flew between the roofs, anxiously searching the horizon, in the hope of spotting the black man. Only Joel knew that his brother could fly [...]. (Scliar, 2004: 31-2)

This fragile boy who did not eat could only fly. He already suffered from the disease that would eventually kill him, the narrator tells us. Ever thinner and constantly coughing, one day Nathan tastes the food from Macumba's lunch-pail and likes the beans and rice and the manioc mush. From then on, Macumba gave him his lunch and got from Shendl a plate with good Yiddish food. They ate together in the back-yard, the black man and the Jewish boy, until one day blood came out of Macumba's mouth. He then said:

"Now we are together, my little friend. But keep the secret." One day, he vanished over near the Morro da Velha, from where he had come, and was never seen again. (Scliar, 2004: 31)

The friendship with Nathan diminishes in a positive way the circumstance of Macumba's adulthood and makes him a friend and companion of the neighborhood boys, to the extent of his also getting sick and disappearing. In this way, the adult's empathy, his descent into the dimensions of a childhood determined by fantasy, composes a dreamscape; in a certain way, Macumba's condition is a proof of his moral greatness. In this sense, childhood and its world miniaturized by the fantasy of war, which invades the neighborhood, the little world of the children, is inversely proportional to the great kindness and peacefulness of the black man Macumba.

In a certain way, the Second World War, however, is what molds the tiny country of Bom Fim. Interspersed with the news from the front, the war games played by the children reproduce on a smaller scale the disasters taking place in Europe:

Bom Fim was standing up for democracy. It organized itself into Rubber Company. In Italy, the Brazilian Expeditionary Force fought from hill to 
hill; in Bom Fim, the trucks went by collecting rubber for making the tires roll for victory. [...]. Hitler (Who is the guy who wears his hair on his forehead, and a moustache that looks like a fly? Ha, ha. clown!) fumed in anger. The Germans retreated in Russia, had failed in the bombing of London, were lost in North Africa... It was too much for that saurkrauteater. In desperation, he decided to invade Bom Fim. (Scliar, 2004: 53)

The war news, which arrived by the big, valve radios that the adults listened to and the newspapers they read, migrate to the fictional discourse from the point-of-view of the children. In this way, it is possible to shuffle fact and fiction and construct a caricature of Hitler. The hair and the ridiculous moustache, the sauerkraut-eater in the novel appears frustrated at the failed attacks on London, Russia, and Africa, and resolves to open up space for the attack on Bom Fim.

This space of fantasy created by the narrator gives the tone of the children's imagination that determines the plot:

The kids saw the tanks coming up Fernandes Vieira Street. Behind them advanced columns of infantry, with flame-throwers. Armored cars with heavy machine-guns took up the rear. And over the roofs droned Stukas and Messerschmitts! Joel quickly organized the defense. With bottles of Charrua, gasoline and rags, they prepared Molotov cocktails and attacked the tanks at the intersection of Fernandes Vieira and Henrique Dias. [...]. They confronted the Germans on the bare terrain beside the garage, where they were dug in. [...]. Joel disposed of a Nazi with his fists, turned the machine-gun on the others and disposed of them as well. [...]. Pieces of Nazis flew in every direction! Not a single one was left. Hundreds of bodies piled up in the field! (Scliar, 2004: 53-5)

With the fragments of the factual war and the imagination, the children do not imitate the world of the adults, but when they interweave the remains of reality with the threads of fantasy; a new and original relation is created. The children construct their world of things, a microcosm in the macrocosm, as Walter Benjamin wrote, in "Old and Forgotten Children's Books." (cf: Benjamin, 1993; 235-238) The child works with the images of the 
war as patches or bricks. With these residuals, he builds his world, gathering all these elements into a single space of fantasy.

Benjamin again, in "Universal History of the Toy," reminds us: "Nuremberg is the fatherland of little lead soldiers and the graceful animals of Noah's Ark. The oldest dollhouse that we have notice of comes from Munich." (Benjamin, 1993: 244) Benjamin analyzes this curious relation between the history of the toy, the miniature, and Germany in a unique way. With the advance of the Reformation, he writes, many artists who were used to working for the Church redirected their production because of the demand for craftsmen's products, making small objects of art for home decoration instead of works on a larger scale. In this way, there occurred "the exceptional diffusion of that world of microscopic things, which were the joy of children in the toy closets and of the adults in the parlor of art and marvels." (Benjamin, 1993: 245)

Considering this microcosm of children's toys as an approximation to the war games in Scliar's novel, one can say, with Benjamin, that the children's world does not constitute a separate community but is a part of a community of the neighborhood, of the country to which they belong. Thus, the children's play in Bom Fim is not a proof of a segregated life, but a dialogue of the children with the community in which they live.

For this reason, to halt the Nazi advance on the Capão da Canoa, and from there prevent the invasion of Bom Fim, a number of characters are summoned: the Submarine Prince, Plastic Man, the Shadow, Samson and Joshua, as well as the boxers Daniel Mendoza, Samuel Elias, Isaac Bittoon, Benny Leonard, among others. Also, Zorro, the Avenger, the Americans, the British, the French, the Russians, the B.E.F., the natives of Capão, and God...

As a cast, all these characters from legend and comics, as well as the Allies and the neighbors from Bom Fim, comprise, with God, an unbeatable army. And yet,

it is not a mere question of mastering terrible, primordial experiences by gradual mitigation, by malicious invocation, by parody; it is a question also of repeatedly savoring, in a more intense way, the same victories and triumphs. The adult alleviates his fear and doubly enjoys his happiness when he tells of his experience. The child recreates this experience, always begins again from the beginning. (Benjamin, 1993: 253) 
The war games told in the novel and fought in Bom Fim by the boys led by Joel are forms of how the narrator shows how the conflict was inscribed in Brazil. Like a Medusa, preventing the petrifying narrative of fact, which, after all, can be read about in the newspapers and heard over the radio, the narrator restages the war in children's games, as in a sandbox. In these spaces, fantasy takes over. The characters of the imagination can therefore fight along with the B.E.F., the community of Bom Fim and even God.

This space ruled by children's knowledge, recreated by a narrator on a smaller scale, allows us to glimpse not only the war and its characters, but also the construction strategies of the imagination and humor in dark times. Jacó Guinsburg, in the introduction to his translation of Teyve, the Milkman, states that "the cheerful therapeutic of sometimes incurable diseases results, no doubt, from an identification with the spectacle around one, which tempers the reason of the understanding with the empathy of feeling. (Guinsburg, 2012: 31)

Far from a flight from reality, this detour brought about by fiction with its peculiar humor, made possible by the children's game, is a weapon against petrified reality and a promise of freedom.

[Translator: Thomas Burns]

\section{Referencies}

Bachelard, Gaston. A poética do espaço. Trad. Antonio de Pádua Danesi. São Paulo: Martins Fontes, 1993.

Benjamin, Walter. Obras escolhidas. Magia e técnica, arte e política. ensaios sobre literatura e história da cultura. v. 1. Trad. Sérgio Paulo Rouanet. São Paulo: Braziliense, 1993.

Borges, Jorge Luis. Jorge Luis Borges. Obras completas. Vários tradutores. v. 2. São Paulo: Globo, 2000.

Guinsburg, Jacó. De como se tenta transformar Téyve em Tobias. In: Aleikhem, Scholem. Téyve, o leiteiro. Organização, tradução, introdução e notas de Jacó Guinsburg. São Paulo: Perspectiva, 2012.

Scliar, Moacyr. A Guerra no Bom Fim. Porto Alegre: L\&PM, 2004. (1972)

. Cenas da vida minúscula. Porto Alegre: L\&PM, 2003. (1991)

. Contos reunidos. São Paulo: Companhia das Letras, 2003b. 